\title{
Formation and disruption of aggregations of Mytilus edulis in the fouling community of San Francisco Bay, California
}

\author{
Beth Okamura* \\ Department of Zoology, University of California, Berkeley, California 94720, USA
}

\begin{abstract}
Successional dynamics of a fouling assemblage in San Francisco Bay were studied on a series of formica plates. Hydroids and barnacles were found to accelerate rates of succession to mussel dominance by facilitating recruitment of young mussels. Development of hydroid colonies along the borders of plates produced an edge effect that was reflected in the pattern of recruitment of mussels onto plates. The importance of edge-to-center ratios on plates of different sizes and shapes to rates of succession is discussed. Substantial annual and seasonal variation in recruitment was found to influence rates of succession to mussel dominance. Disruption of mussel dominance occurred when a mixed school of surfperch took up temporary residence. Predation on mussels by surfperch allowed other species to become established on plates, thereby promoting a more diverse assemblage, however disruption of mussel dominance by surfperch appears to be an unpredictable event, and local sites may be dominated for many years by a monoculture of mussels.
\end{abstract}

\section{INTRODUCTION}

Patterns of succession in the rocky intertidal of the Pacific Northwest have been extensively investigated (Dayton 1971, Paine 1974, 1976, Paine \& Levin 1981). In this system the mussel Mytilus californianus is the dominant competitor for space and forms extensive beds. The rapid growth to large size, the possession of strong shells that can crush and squeeze out neighbors, and the ability to detach and reattach to the substratum with their byssal threads may explain the competitive dominance achieved by mussels in their habitats (Jackson 1983). Species that are competitively inferior to $M$. Californianus persist in the intertidal by colonizing clearings of varying sizes that are created by predation and physical disturbance to mussel beds.

Recently, the successional role of Mytilus edulis has been investigated in several subtidal systems (Dean \& Hurd 1980, Schoener \& Schoener 1981, Chalmer 1982, Greene \& Schoener 1982). In these systems $M$. edulis has been observed to dominate space rapidly, displaying similar patterns to those of its congener, Mytilus californianus in the Pacific Northwest. Dean \& Hurd

- Present address: Smithsonian Marine Station at Link Port, Route 1, Box 194-C, Fort Pierce, Florida 33450, USA
(1980) showed that early colonists can both facilitate and inhibit the rates of succession to dominance by $M$. edulis. This pattern of dominance by mussels has been contrasted to Jackson's $(1977,1983)$ observation of dominance by colonial organisms in most subtidal habitats (Greene \& Schoener 1982).

This paper describes the successional patterns leading to dominance by Mytius edulis in the subtidal fouling assemblage of San Francisco Bay. Particular attention will be given to the ways in which patterns of establishment of $M$. edulis and rates of succession to dominance by $M$. edulis can be affected by: (1) the presence of prior occupants; (2) the size and shape of the area on which succession is occurring; and (3) annual and seasonal variation in recruitment patterns. Finally, the observed disruption of dominance by mussels caused by predatory surfperch and the implications of this disruption to levels of diversity in this community will be discussed.

\section{STUDY SITE AND GENERAL METHODS}

Research was conducted below the pier of the National Marine Fisheries Service Southwest Laboratories in Tiburon, California. The pier extends 
approximately $70 \mathrm{~m}$ into San Fancisco Bay, is subject to strong flooding and ebbing tidal currents, and receives mild to moderate wave action but is not subject to open ocean swell. Human disturbance is minimal as the pier is closed to the public.

To study the fouling community of the Tiburon pier a floating platform (or 'float') was built and positioned beneath the pier. Plastic panels were partially submerged from the float, and textured, white, formica plates were attached to the horizontal undersurfaces of these plastic panels. With the exception of certain experiments on patch size and shape, these plates were 15.24 by $15.24 \mathrm{~cm}$ in size. Community development was studied on formica plates because this material had proved, in pilot experiments and earlier studies (Schoener \& Schoener 1981) to be attractive to settling larvae.

Every 4 to $5 \mathrm{wk}$ plates were detached from the plastic panels, immersed in a pan of seawater, and sampled nondestructively. A plexiglass grid of 100 random points was positioned above the plate and the various species and bare space that lay below the points were recorded. Through this procedure, the percent covered by different species and by bare space was estimated. The number of points sampled was greater than that required to accurately estimate cover to within $5 \%$ when cover is determined by planimeter readings as reported by Sutherland \& Karlson (1977). The data on percent cover were normalized through arcsine transformations prior to statistical analysis.

The sampling grid was divided into peripheral and central areas when the hydroid Tubularia crocea appeared to become established more on the edges of plates. Each region had an equal number of random points per unit area. The periphery of the plates was identified as a $3.81 \mathrm{~cm}$ zone around the outer edge. The width of this zone approximated the average diameter of established colonies of $T$. crocea on the plates. In cases where an organism lay on the boundary of the peripheral or central areas of the plate, it was recorded as occurring in that area in which it occupied the most space.

Organisms with upright growth forms were often present. The percent cover of this 'canopy' layer was recorded, and the composition of the understory at that point was determined. Thus percent cover data were obtained for organisms inhabiting 2 levels: (1) organisms occupying primary space in direct attachment to the plate at that point (these organisms may or may not have an overlying canopy); and (2) organisms occupying the canopy level above the plate. Overtopping of one canopy level by another was rare and not a confounding factor in the sampling method.

Successional patterns were documented for about 16 mo on plates that were initially submerged on
August 27, 1980. To study seasonal effects on successional patterns, sets of plates were submerged on July 3, 1982 and on September 5, 1982. These plates were sampled until early February of 1983 when a storm destroyed the float.

\section{RESULTS}

\section{Pattern of succession to dominance by mussels}

After the initial establishment of a diatom film plates were colonized by the hydroid Tubularia crocea (see Fig. 1). (See Table 1 for identities of those species, by group, that on average occupied at least $5 \%$ of plate surfaces at any time during the study.) Soon after the establishment of $T$. crocea, a suite of nudibranchs appeared /Cumanotus beaumonti, Hermissenda crassicornis, Coryphella trilineata, and Dendronotus frondosus). These nudibranchs grazed on the hydranths of $T$. crocea and laid egg masses among the stems (hydrocauli) of the hydroid colonies and on the plates themselves. $T$. crocea colonies exhibited no further increases in percent cover from this point on (Oct 21 , 1980), but began to regress slowly, degenerating to short stumps by spring.

On December 22, 1980 the subsampling of peripheral and central areas of plates was initiated. A significantly greater percent cover of Tubularia crocea colonies was found in primary space (i.e. not the canopy space) in peripheral areas than in the central areas of plates (paired Student's t-test; $t=5.658$,

Table 1. List of species that occupied a mean of at least $5 \%$ of plate surfaces at any time during the study

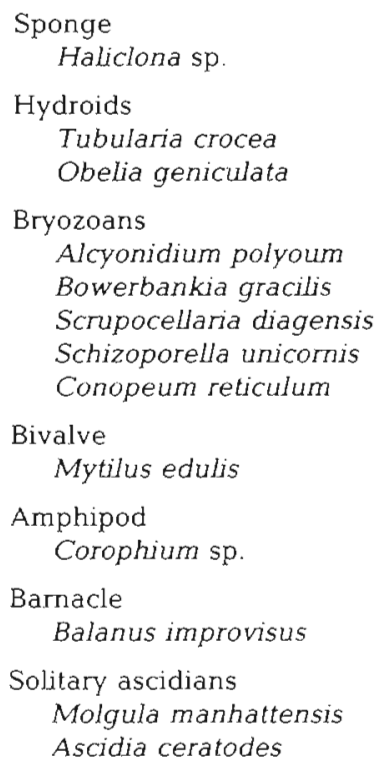




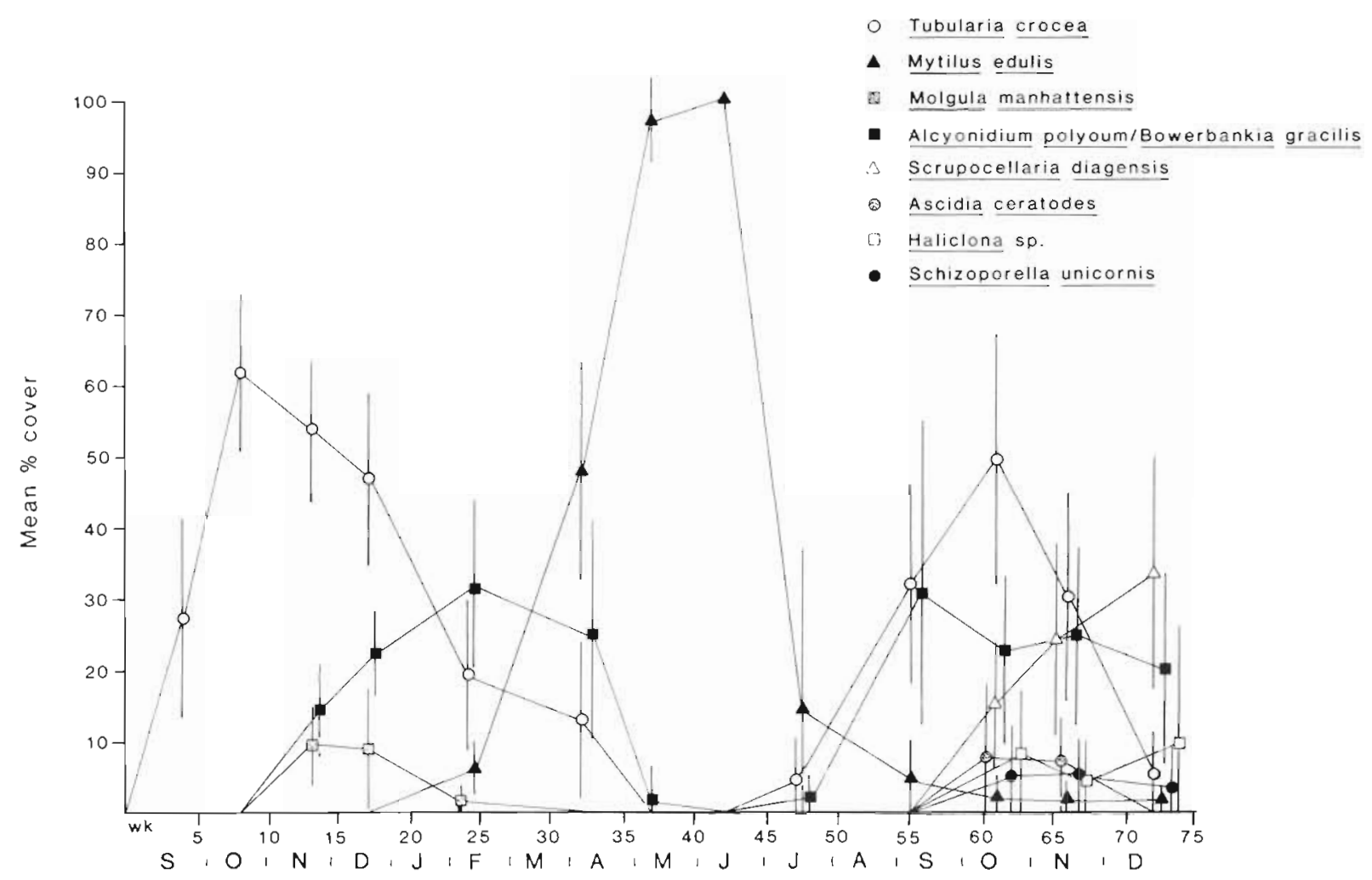

Fig. 1. Mean percent cover of species occupying $\geq 5 \%$ of the plate surfaces from Aug 27, 1980 to Dec 24, 1981. Bars represent $1 \mathrm{SD}$ on either side of the mean. The number of points sampled per period was reduced from 32 to 4 over the course of the study due to loss of plates through storm damage and sacrificing plates when experiments were initiated

$\mathrm{p}<0.001, \mathrm{n}=18$ ). Plates submerged during a period when $T$. crocea was colonizing the substratum (summer 1981) indicated that the greater peripheral abundance of $T$. crocea colonies may reflect patterns of larval settlement rather than subsequent differential growth and mortality of colonies. The average density of newly-metamorphosed $T$. crocea colonies in the center was $1.9 \mathrm{~cm}^{-2}$, compared to $4.0 \mathrm{~cm}^{-2}$ on the edges of plates. These values differed significantly (matched pair Student's t-test, $t=5.145, p<0.001$, $\mathrm{n}=36)$.

Several other species occupied a substantial amount of space (e.g. the solitary ascidian Molgula manhattensis, the encrusting bryozoan Alcyonidium polyoum, and the stoloniferous bryozoan Bowerbankia gracilis which formed dense mats) during the winter months of 1980/1981; however by spring of 1981 the mussel Mytilus edulis was rapidly assuming complete dominance. Mussels first began to appear in February 1981 as young plantigrades (Bayne 1964) attached to the degenerate hydrocauli and stolons of Tubularia crocea colonies. This positive association of young mussels with the hydroid colonies was reflected by a greater initial percent cover of mussels on the edges of plates (mean $=7.0 \%$ ) where significantly more $T$. crocea colonies had become established (see above) than in the centers of plates (mean $=1.4 \%$ ) (matched pair Student's test; $\mathrm{t}=5.532, \mathrm{p}<0.001, \mathrm{n}=17$ ).

As Mytilus edulis grew, the mussels began to move away from their initial sites of recruitment among the degenerate colonies of Tubularia crocea. Further recruitment of $M$. edulis occurred, especially around established mussels, and by June 15, 1981 all plates were dominated by a $100 \%$ cover of $M$. edulis. The pattern of mussel dominance, however, began to be disrupted in July. The cause of this disruption will be discussed later. With the disappearance of mussels, earlier colonists reinvaded the system ( $T$. crocea, Bowerbankia gracilis, and Alcyonidium polyoum, but not Molgula manhattensis). Reinvasion probably resulted from regrowth of colonies previously restricted to small pockets amongst the mussels, regrowth of degenerate colonies present below the mussels, and colonization by larvae. The upright bryozoan Scrupocellaria diagensis also colonized the plates and became quite abundant.

The development of a substantial canopy of Tubularia crocea by the fall of 1981 presented a large area of filamentous substrata that might again have attracted the recruitment of mussel plantigrades. 
Unfortunately, this phenomenon was not documented because the float and plates were lost during a severe storm in early January 1982.

During the summer of 1982 a new series of plates was submerged from a new float to follow the sequence of species replacements through time. Fig. 2A depicts the average percent cover of species occupying plates originally submerged on July 3, 1982. (See Table 1 for species' group identities). Again, plates were initially colonized by diatoms, however during that summer, little Tubularia crocea became established. Instead, brief residencies by tubiculous amphipods (Corophium sp.) and the hydroid Obelia geniculata were followed by near dominance of barnacles (Balanus improvisus). Barnacles were also observed to dominate the pier pilings during the course of the study. Mussel plantigrades recruited in and among the crevices offered by the barnacle tests, and by the end of December 1982, mussels held an average of $60 \%$ of the plate surface area. Mussels were observed to recruit among the barnacles on the pier pilings during the same period.

In contrast to plates submerged in July, plates submerged in September 1982 developed no barnacle cover and also attracted an inconsequential number of mussels (see Fig. 2B). The absence of mussels on these plates seems to reflect a lack of attractive substrata (e.g. crevices of barnacle tests or stems of hydroids) for the recruitment of plantigrades, since both the barnacle-dominated July series of plates and the September plate series were submerged at the time of mussel settlement.

\section{Disruption of mussel dominance}

In July 1981, openings were observed within the homogeneous matrix of mussels (see Fig. 1). It was at this time that mixed schools of surfperches (Family: Embiotocidae) were seen foraging among the plates and along the pier pilings (where mussels were also present). Several of these fish were caught and identified as Embiotica lateralis (the striped surfperch) and Damalichthys vacca (the pile surfperch). Both species feed on mussels in San Francisco Bay (Haldorson \& Moser 1979), and analysis of the gut contents of the fish revealed that both species had been consuming mussels. $D$. vacca individuals had fed almost exclusively on mussels. $D$. vacca has heavy pharyngeal teeth with large associated musculature and has been shown to specialize on hard-shelled organisms (Brett 1979, Hal-
A

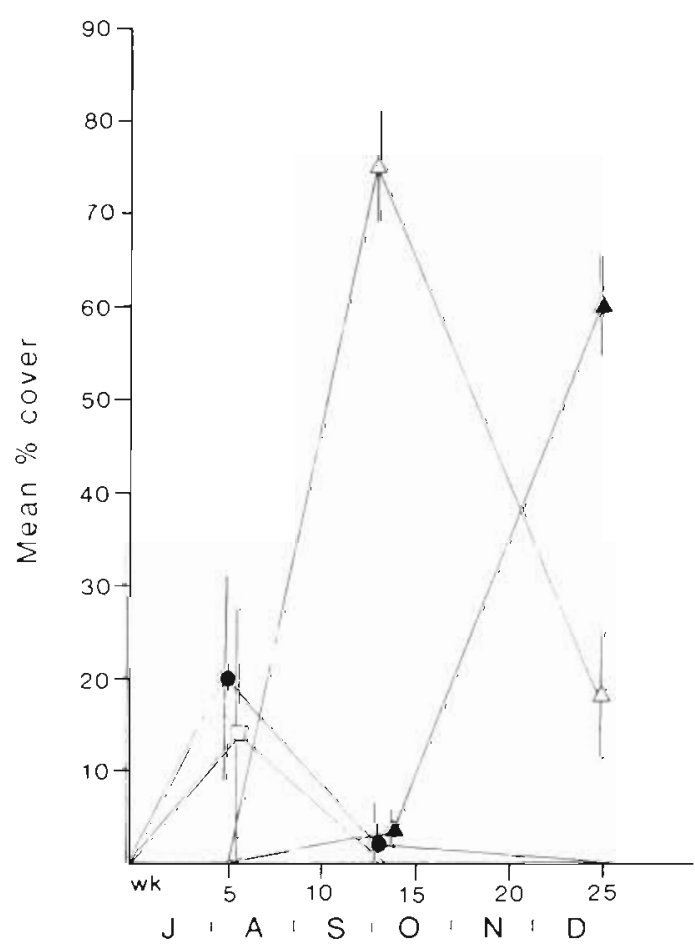

B

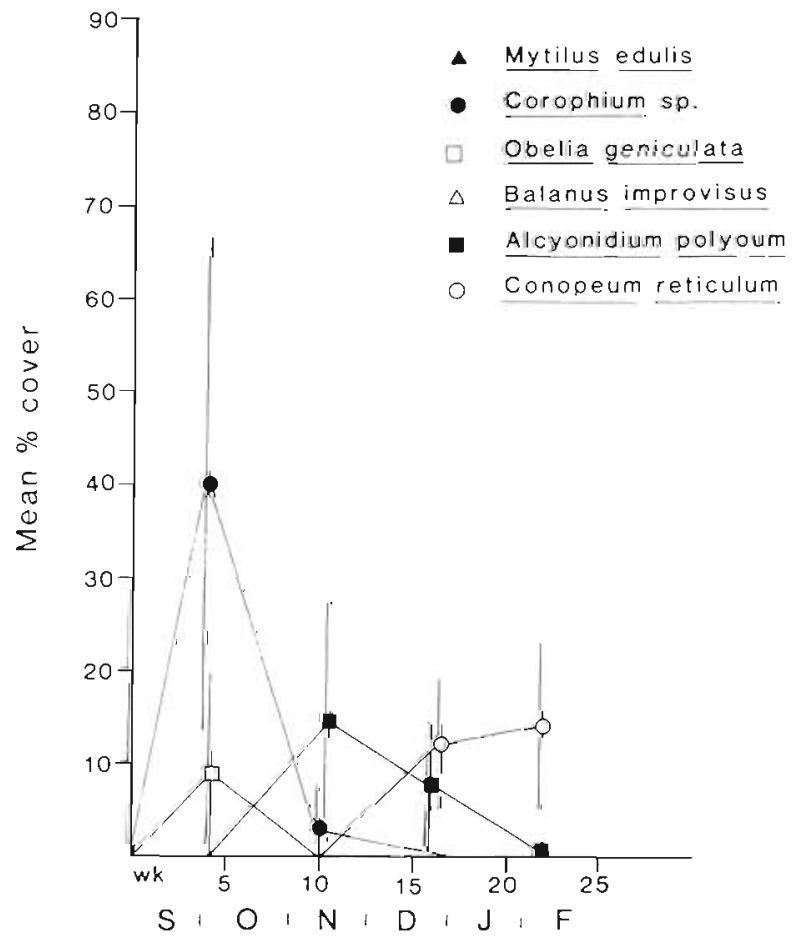

Fig. 2. Mean percent cover of species occupying $\geq 5 \%$ of the plate surfaces. (A) Mean percent cover of plates submerged Jul 3 , 1982 ( $n=5$ plates); (B) mean percent cover of plates submerged Sep 5, $1982(n=6$ plates). Bars represent 1 SD on either side of the mean 
dorson \& Moser 1979). Size preference was casually observed by dropping mussels into the water and noting that mussels larger than approximately $20 \mathrm{~mm}$ in length were ignored by fish while smaller mussels were readily consumed.

Throughout the period that mussels were disappearing surfperch were observed foraging among the plates. By the end of August 1981 the mussels had been virtually cleared from all plates (see Fig. 1) and only a few rare individuals were left. At this time the school of surfperch disappeared. The plates, having been cleared of mussels, began to be colonized by species typically occurring earlier in succession, and by several species that had not been observed before (see Fig. 1).

\section{DISCUSSION}

\section{Effect of prior occupants on succession to mussel dominance}

Early colonists can play critical roles in the development of species assemblages by facilitating or inhibiting the recruitment of later colonists (Connell \& Slatyer 1977). Plantigrades of Mytilus edulis are attracted to settle amongst filamentous or pitted substrata (De Blok \& Geelen 1958, Bayne 1964, Seed 1969, Dean \& Hurd 1980, Brault \& Bourget 1985), and in this study facilitation of mussel recruitment by the early colonists Tubularia crocea and Balanus improvisus reflected this attraction. The presence of hydroids or barnacles thus enhanced rates of succession to dominance by the long-lived, dominant species in the community. A hydroid-tunicate assemblage (T. crocea and Molgula manhattensis) was found to facilitate the settlement of Mytilus edulis in the subtidal fouling assemblage of the Broadkill River estuary in Delaware (Dean \& Hurd 1980), and mussel recruitment was enhanced by the presence of barnacles in the New England intertidal (Menge 1976). These studies suggest that the presence of earlier colonists can accelerate succession to dominance by $M$. edulis in a number of systems.

\section{Edge effects}

Many investigators have ignored the edges of experimental quadrats (e.g. Keen \& Neill 1980, Russ 1980, Chalmer 1982), however organisms can respond differentially to patches of habitat and thereby may exert potentially important 'edge effects'. Edge effects can result from patterns in the settlement of organisms (Bernstein \& Jung 1979, Schoener \& Schoener 1981, this study), and they have been shown to arise through the action of grazers in a number of systems (Randall
1965, Bartholomew 1970, Dayton 1971, Ogden et al. 1973, Stimson 1973, Suchanek 1978, Paine \& Levin 1981, Sousa 1984).

Patches are thus often structurally heterogeneous areas of habitat reflecting the differential responses of organisms. While this study and several others (Paine \& Levin 1981, Schoener \& Schoener 1981) imply that edge effects may influence rates of succession to the competitive dominant, the importance of edge effects to successional dynamics has received little investigation. It is clear that to gain an understanding of patch dynamics in a number of systems it may be necessary to subdivide our scales of observation and to study areas of habitat in finer detail.

\section{Edge effects, patch size and shape, and rates of succession}

Since the relative ratio of edge-to-center varies as the size and shape of patches vary, it can be expected that patch size and shape can also influence rates of succession. For instance, in this study a sufficiently long and narrow plate will be perceived as 'all edge' by Tubularia crocea, and colonies will become established over the entire area of the plate. A shorter, wider plate of the same area will develop a distinct edge with $T$. crocea colonies and a central area devoid of hydroids. One would therefore predict that rates of succession to mussel dominance, given the presence of $T$. crocea, should be highly dependent on plate size and shape and will occur most rapidly on plates with the greatest edge-to-center ratios. Conversely, plate size and shape should have little effect on rates of convergence to mussel domination on plates with barnacles. Barnacles show no marked tendency to become established in particular areas of plates but rather are abundant over their entire surfaces. In this study, the experimental determination of the effects of plate size and shape on rates of convergence to mussel dominance did not succeed because it was impossible to leave the float in the water through the severe winter periods.

Several other investigations also provide evidence that interactions between edge effects and patch size and shape can influence rates of succession. Patches in beds of Mytilus californianus that are small enough to be completely incorporated within limpet browse zones have been observed to become rapidly dominated by mussels because large macroalgae do not develop (Paine \& Levin 1981). Schoener \& Schoener (1981) found that large plates with large central areas were slow to be colonized by fouling organisms relative to smaller plates with larger edge-to-center ratios.

In summary, evidence suggests that edge effects can 
interact with the sizes and shapes of patches in a complex fashion. Because edge effects arise from differential organismal responses to patches of habitat the nature of this interaction can be expected to vary from system to system. An understanding of the biology of the species peculiar to a given situation may often be necessary to explain observed patterns.

\section{Annual and seasonal variation in larval recruitment}

While the spatial position of prior occupants and the size and shape of the clearing being colonized may affect rates of succession, a factor having much greater potential influence on rates of succession in this system is annual variation in recruitment. Such variation has been observed in a variety of marine communities (e.g. Loosanoff \& Nomejko 1956, Southward \& Crisp 1956, Loosanoff 1964, 1966, Bowman \& Lewis 1977, Sutherland \& Karlson 1977. Hawkins \& Hartnoll 1982, Kautsky 1982, Keough 1983, Brault \& Bourget 1985, Caffey 1985, Connell 1985, Kendall et al. 1985), however its general importance may be largely unappreciated since relatively long term studies are required to document its effects on community structure.

In this study, Tubularia crocea developed high percent cover values in the late summer/early fall of 1980 and 1981, but in $1982 T$. crocea was not abundant. Similar annual variation in the recruitment of T. larynx has been observed in Britain (Schmidt 1983). Various abiotic or biotic factors might explain the variation observed at Tiburon. The winter of $1981 / 1982$ was characterized by unusually heavy rainfall, and the reduced salinities and/or possibly greater turbidity in San Francisco Bay may have affected recruitment of $T$. crocea during the following summer. The development of a substantial cover of tubiculous amphipods in the fall of 1982 suggests that the water that year was very turbid (Barnard 1958). On the other hand, recruitment by $T$. crocea may be highly localized. $T$. crocea produce short-lived larvae that are thought to crawl away upon release; however recruitment to plates indicates a water-borne phase. The timing of their release combined with the pattern of local water movements may produce substantial year-to-year variation in abundance at any one site. Rates of succession to mussel dominance in the absence of prior occupants that facilitate mussel recruitment should be substantially reduced

Seasonal variation in larval recruitment can also exert strong effects on rates of succession to the community dominant (e.g. Sutherland 1974, Osman 1977, Sutherland \& Karlson 1977). In this study, plates that were submerged 2 mo apart developed very different assemblages of early colonists. Of great significance was the substantial percent cover of barnacles that developed on the July series of plates but not on the September series. The recruitment of Mytilus edulis plantigrades to pitted, grooved surfaces (Seed 1969) probably explains the subsequent patterns of development on these 2 series of plates since mussel larvae were available for settlement when both series of plates were submerged.

\section{Disruption of mussel dominance and maintenance of diversity}

The temporary residence and disappearance of surfperch at the study site support the idea that surfperch move around San Francisco Bay making periodic stopovers at various sites (Moser pers. comm.). Surfperch, however, do not appear to be regular visitors. The undersurfaces of a float used for fish culture that had been removed from an area adjacent to the study site in the fall of 1980 were completely dominated by mussels. This float had been in the water for over a year, and the mussels growing on it were relatively large (mean length $=26.37 \mathrm{~mm}, \mathrm{SD}=11.53$, median length $=26 \mathrm{~mm}$, range $=8$ to $67 \mathrm{~mm}, \mathrm{n}=134$ ). Surfperch appear to avoid preying on mussels beyond a certain critical size, thus if mussels become large enough they may be ignored. The majority of mussels living on the fish culture float had attained sizes evidently too large to be preyed upon by surfperch. Barring other sources of mortality, it appeared that this aggregation of mussels was potentially long-lived since Mytilus edulis can live for 18 to $24 \mathrm{yr}$ (Seed 1976). Evidently, surfperch had not visited the local area when the mussels were smaller.

This study indicates that the species composition of the fouling community in San Francisco Bay at any one locality is dependent on the past history of disturbance. If undisturbed, the site will soon be dominated by a monoculture of mussels. Similar escapes in predation due to size by the mussel Mytilus californianus have been observed (Paine 1976). If surfperch visit before the mussels have grown large enough to escape fish predation, the site may support a number of species. Visitations by surfperch appear to be unpredictable, and the communities at different sites may vary in successional age. The diversity of the fouling community on a regional scale will therefore depend on the visitation patterns of schools of surfperch to local sites within the system as well as on the timing of other potentially disruptive influences not identified in this study.

The maintenance of diversity by fish predation as described above is similar to the maintenance of diversity by predation and physical disturbance in the 
exposed rocky intertidal of the Pacific Northwest where the mussel Mytilus californianus is the dominant spatial competitor (Dayton 1971, Paine 1974, 1976, Paine \& Levin 1981). Several other investigations of subtidal systems show that predation of the competitive dominant by fish can maintain diversity (Sutherland 1974, Day 1977, Russ 1980, Ayling 1981). Predaceous fish may thus often play an important role in the organization of subtidal marine communities.

\section{CONCLUSION}

This study indicates that rates of succession to dominance by Mytilus edulis in the fouling community of San Francisco Bay can be influenced by prior occupants and by variation in recruitment on both an annual and seasonal basis. Similar results obtained from earlier investigations of mussel-dominated communities as well as from other marine assemblages provide support for the general importance of such phenomena.

The pattern of development of hydroid colonies along plate borders resulted in an initially greater mussel cover on plate edges because mussel larvae were attracted to recruit among hydroid colonies. This observation has important implications to rates of succession on plates of varying size and shape. Differential organismal responses to patches of habitat may exert strong influences on the subsequent dynamics within patches. Treating experimental quadrats as homogeneous units may therefore often sacrifice valuable information that could be documented if the scales of observation are subdivided.

Disruption of mussel dominance and the maintenance of diversity in this subtidal community is effected by schools of predatory surfperch. It appears that fish may be important predators of the competitive dominants in many subtidal systems. Evidence was found, however, to suggest that surfperch visitations at any particular site are unpredictable, and mussels may grow to sizes at which they become invulnerable to predation by surfperch. Local sites may then be dominated for many years by a monoculture of mussels.

Acknowledgements. This research could not have been accomplished without the generous help in field sampling and in the construction and maintenance of floats provided by: A. Austin, N. Barton, R. Everett, T. Lim, R. Lum, J. Okamura, P. Pressley, G. Roderick, B. Rogers, W. Sousa, P. Tibbetts, and R. Zoller To all I am grateful.

The National Marine Fisheries Service Southwest Laboratories in Tiburon kindly provided access to their private pier, and their members of staff, $B$. Jarvis and $M$. Eldnidge, were most generous in logistical support.

I am deeply grateful to my major professors, W. Sousa and
M. Koehl, for their support, advice, friendship, and encouragement throughout my graduate career.

The research described here was submitted as partial fulfillment of the requirements of the $\mathrm{Ph} . \mathrm{D}$. in the Department of Zoology, University of California, Berkeley and received support from a grant-in-aid of research from the Sigma Xi Society.

Critical reading of this manuscript by W. Sousa, M. Koehl, R. Hughes, M. Phillips, E. Tuomi, and 3 anonymous reviewers has improved its quality.

This is contribution No. 169 from the Smithsonian Marine Station at Link Port

\section{LITERATURE CITED}

Ayling, A. M. (1981). The role of biological disturbance in temperate subtidal encrusting communities. Ecology 62: $830-847$

Barnard, J. L. (1958). Amphipod crustaceans as fouling organisms in Los Angeles-Long Beach harbors with special reference to the influence of seawater turbidity. Calif. Fish Game 44: 161-170

Bartholomew, B. (1970). Bare zone between California shrub and grassland communities: the role of animals. Science 170: $1210-1212$

Bayne, B. L. (1964). Primary and secondary settlement in Mytilus edulis L. (Mollusca). J. Anim. Ecol. 33: 512-523

Bernstein, B. B., Jung, N (1979). Selective pressures and coevolution in a kelp canopy community in southern California, U.S.A. Ecol. Monogr. 49: 335-355

Blok, J. W. de, Geeelen, H. J. (1958). The substratum required for the settling of mussels (Mytilus edulis). Archs, néerl. Zool. 13: 446-460

Bowman, R. S., Lewis, J. R. (1977). Annual fluctuations in the recruitment of Patella vulgata. J. mar. biol. Ass. U.K. 57: $793-816$

Brault, S., Bourget, E. (1985). Structural changes in an estuarine subtidal epibenthic community: biotic and physical causes. Mar. Ecol. Prog. Ser. 21: 63-73

Brett, J. R. (1979). Some morphological and behavioural adaptations of pile perch (Rhacochilus vacca) feeding on mussels (Mytilus edulis). Can. J. Zool. 57: 658-664

Caffey, H. M. (1985). Spatial and temporal variation in settlement and recruitment of intertidal. barnacles. Ecol. Monogi. 55: 313-332

Chalmer, P. N. (1982). Settlement patterns of species in a marine fouling community and some mechanisms of succession. J. exp. mar. Biol. Ecol. 58: 73-85

Connell, J. H. (1985). The consequences of variation in initial settlement vs. post-settlement mortality in rocky intertidal communities. J. exp. mar. Biol. Ecol. 93: 11-45

Connell, J. H., Slatyer, R. O. (1977). Mechanisms of succession in natural communities and their role in community stability and organization. Am. Nat. 111: 1119-1144

Day, R. (1977). Two contrasting effects of predation on species richness in coral reef habitats. Mar. Biol. 44: 1-6

Dayton, P. K. (1971). Competition and community organization: the provision and subsequent utilization of space in a rocky intertidal community. Ecol. Monogr. 41: 351-389

Dean, T. A., Hurd, L. E. (1980). Development in an estuarine fouling community: the influence of early colonists on later arrivals. Oecologia (Berl.) 46: 295-301

Greene, C. H., Schoener, A. (1982). Succession on marine hard substrata: a fixed lottery. Oecologia (Berl.) 55: 289-297

Haldorson, L., Moser, M. (1979). Geographic patterns of prey 
utilization in two species of surfperch (Embiotocidae). Copeia 4: 567-572

Hawkins, S. J., Hartnoll, R. G. (1982). Settlement patterns of Semibalanus balanoides in the Isle of Man (1977-1981). J. exp. mar. Biol. Ecol. 62: 271-283

Jackson, J. B. C. (1977). Competition on marine hard substrata: the adaptative significance of solitary and colonial strategies. Am. Nat. 111: 743-767

Jackson, J. B. C. (1983). Biological determinants of present and past sessile animal distributions. In: Tevesz, M.J.S., McCall, P. L. (ed.) Biotic interactions in recent and fossil benthic communities. Plenum, New York, p. 39-120

Kautsky, N. (1982). Growth and size structure in a Baltic Mytilus edulis population. Mar. Biol. 68: 117-133

Keen, S. L., Neill, W. E. (1980). Spatial relationships and some structuring processes in benthic intertidal animal com. munities. J. exp. mar. Biol. Ecol. 45: 139-156

Kendall, M. A., Bowman, R. S., Williamson, P., Lewis, J. R. (1985). Annual variation in the recruitment of Semibalanus balanoides on the north Yorkshire coast 1969-1981. J. mar. biol. Ass. U.K. 65: 1009-1030

Keough, M.J. (1983). Pattems of recruitment of sessile invertebrates in two subtidal habitats. J. exp. mar. Biol. Ecol. 66: 213-245

Loosanoff, V. L. (1964). Variation in time and intensity of setting of the starfish Asterias forbesi, in Long Island Sound during a twenty-five year period. Biol. Bull. mar. biol. Lab., Woods Hole, 126: 423-439

Loosanoff, V. L. (1966). Time and intensity of settling of the oyster, Crassostrea virginica in Long Island Sound. Biol. Bull. mar. biol. Lab., Woods Hole 130: 211-227

Loosanoff, V W., Nomejko, C. A. (1956). Relative intensity of oyster setting in different years in the same areas of Long Island Sound. Biol. Bull. mar. biol. Lab., Woods Hole 3: 387-392

Menge, B. A. (1976). Organization of the New England rocky intertidal community: role of predation, competition, and environmental heterogeneity. Ecol. Monogr. 46: 355-393

Ogden, J. C., Brown, R. A., Salesky, N. (1973). Grazing by the echinoid Diadema antillarum phillipi: formation of halos around West Indian patch reefs. Science 182: 715-717

Osman, R. W. (1977). The establishment and development of a marine epifaunal community. Ecol. Monogr. 47: 37-64

Paine, R. T. (1974). Intertidal community structure: experimental studies on the relationship between a dominant competitor and its principal predator. Oecologia (Berl.) 15: 93-120

Paine, R. T. (1976). Size-limited predation: an observational and experimental approach with the Mytilus-Pisaster interaction. Ecology 57: 858-873

Paine, R. T., Levin, S. A. (1981). Intertidal landscapes: disturbance and the dynamics of pattern. Ecol. Monogr. 51: $145-178$

Randall, J. E. (1965). Grazing effect on sea grasses by herbivorous reef fishes in the West Indies. Ecology 46 : $255-260$

Russ, G. R. (1980). Effects of predation by fishes, competition, and structural complexity of the subtratum on the establishment of a marine epifaunal community. J. exp. mar. Biol. Ecol. 42: 55-69

Schmidt, G. H. (1983). The hydroid Tubularia larynx causing 'bloom' of the ascidians Ciona intestinalis and Ascidiella aspersa. Mar. Ecol. Prog. Ser. 12: 103-105

Schoener, A., Schoener, T. W. (1981). The dynamics of the species-area relation in marine fouling systems: 1 . Biological correlates of changes in the species-area slope. Am. Nat. 118: 339-360

Seed, R. (1969). The ecology of Mytilus edulis L. (Lamellibranchiata) on exposed rocky shores. I. Breeding and settlement. Oecologia (Berl.) 3: 277-316

Seed, R. (1976). Ecology. In: Bayne, B. L. (ed.) Marine mussels: their ecology and physiology. Cambridge University Press, London, p. 13-65

Sousa, W. P. (1984). Intertidal mosaics: patch size, propagule availability, and spatially variable patterns of succession. Ecology 65: 1918-1935

Southward, A. J., Crisp, D. J. (1956). Fluctuations in the distribution and abundance of intertidal barnacles. J. mar. biol. Ass. U.K. 35: 211-229

Stimson, J. (1973). The role of territory in the ecology of the intertidal limpet Lottia gigantea (Gray). Ecology 54: 1020-1030

Suchanek, T. H. (1978). The ecology of Mytilus edulis L. in exposed rocky intertidal habitats. J. exp. mar. Biol. Ecol. 31: 105-120

Sutherland, J. P. (1974). Multiple stable points in natural communities. Am. Nat. 108: 859-873

Sutherland, J. P., Karlson, R. H. (1977). Development and stability of the fouling community at Beaufort, North Carolina. Ecol. Monogr. 47: 425-446 